\title{
Improving the Rheological Properties of Cross-linked Hyaluronic Acid Gels by Mixing in Mannitol as a Radical Scavenger
}

E Sle Kim, Bokryul Choi, Ju Hee Kang, Keyong Ho Lee

Across, Chuncheon-si, Gangwon-do, Korea

"Corresponding author: Keyong Ho Lee, Across, 23, Geodudanji 1-Gil, DongnaeMyeon, Chuncheon-si, Gangwon-do 24398, Korea

Tel.: +82 332640963

Fax: +82 332640964

Email: keyho625@naver.com

Received November 8, 2018

Revised January 28, 2019

Accepted February 8, 2019

Published March 30, 2019

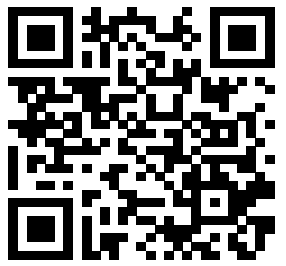

\begin{abstract}
Purpose: This study aimed to evaluate the effect of mixing mannitol into crosslinked hyaluronic acid gels on their rheological properties. Methods: Cross-linked hyaluronic acid gels were prepared by mixing in mannitol to our own manufacturing process, and then the changes in their rheological properties due to chemical and thermal oxidative stress were investigated. The rheological factors evaluated were the storage modulus ( $\left.G^{\prime}\right)$, loss modulus ( $\left.G^{\prime \prime}\right)$, complex viscosity $\left(G^{*}\right)$ and phase angle $(P / A)$. Results: Mixing mannitol into the cross-linked hyaluronic acid gels caused their elasticity (G') and viscosity (G") to resist both frequency increase and oxidative stress caused by chemical and thermal stress. Adding mannitol also resulted in improved urine secretion in an animal model, and we therefore expect that it will reduce edema due to osmotic pressure. Conclusion: Mannitol's antioxidant effect contributed to the improving the cross-linked hyaluronic acid gels' rheological properties.
\end{abstract}

Keywords: Hyaluronic acid, Mannitol, Cross-linked gel, Rheology, Oxidative stress

\section{Introduction}

Hyaluronic acid (히알루론산)은 분자량 5 만 내지 1,000 만 dalton의 무색 투명한 고점도 선형 다당류이며, 반복단위인 glucuronic acid와 N-acetyl glucosamine이 (1-3)과 (1-4) 로 번갈아 결합되어 있다. 히알루론산은 피부, 눈의 초자체, 관 절액, 탯줄, 닭 벼슬 등에 널리 분포되어 있으며, Streptococcus 속 등의 박테리아에 의해 생성되기도 한다(Kogan et al., 2007). 상업적으로 생산이 가능한 히알루론산은 닭 벼슬이나 탯 줄 등과 같은 생체조직으로부터 추출 및 정제하여 얻어지는 히 알루론산과 미생물(주로 Streptococcus 속)을 배양하여 추출 및 정제로부터 생산한 히알루론산이 있다(Chien \& Lee, 2007; Chong \& Nielsen, 2003). 이러한 히알루론산의 사용은 주로 윤 활 효과 및 세균 등의 침입에 대한 보호 효과가 있어 화장품 첨가 제, 안과 수술 시 눈조직의 보호제, 퇴행성 관절염 치료제 및 조 직수복용 의료기기(주로 성형필러) 등 광범위하게 사용되고 있 다(Chong et al., 2005; da Costa et al., 2017; Kwon et al.,
2013).

이러한 히알루론산의 경우 화장품, 안과 및 관절주사 제품에는 히알루론산 자체로 아무런 화학적 처리없이 그대로 사용하는 경 우가 과거에는 대부분이었다. 하지만 최근에는 관절주사를 포함 하여 미용성형 분야에서 히알루론산을 화학적으로 수식을 통하 여 새로운 형태로 사용하는 연구 및 제품 출시 사례가 증가하고 있다(Cameli et al., 2016; Ha et al., 2017). 히알루론산의 체 내 반감기는 그 분자량의 양상에 따라서 차이는 있으나 일반적으 로 혈액내에서는 3-5 $\mathrm{min}$, 피부에서는 1 일 이내이며 관절강 내 에서 약 3 주 정도의 반감기를 갖는 것으로 알려져 있다(Fraser et al., 1981; Laurent et al., 1991; Reed et al., 1990). 따 라서 이러한 히알루론산의 분해 특성으로는 조직수복을 위한 피 부 보충재나 관절 내에서의 윤활 역할을 하는 관절주사제로의 기 능성 특성에는 한계가 있어, 체내에서의 반감기를 연장시켜서 충분히 피부나 관절강 내의 조직보충 및 윤활 역할을 위하여 화 학적으로 수식이 되어 있는 가교 히알루론산 겔(cross-linked hyaluronic acid gel) 제조연구가 많이 진행 되었고(De Boulle 
et al., 2013), 현재는 이러한 가교 기술을 이용한 제품 들이 다 양하게 출시되어 조직 보충재 및 관절주사제로 사용되고 있다.

가교가 되지 않은 히알루론산과는 달리 cross-linked hyaluronic acid gel은 구조 자체가 변경이 되어 있어서 체내 에 주입이 되었을 경우에 히알루론산과는 다른 면역반응을 나 타낼 수 있어, 이것은 예상하지 못하는 부작용을 나타낼 수 있 다. Funt와 Pavicic의 조사연구에 의하면 세계적으로 허가된 제품의 경우 50 여개 이상의 업체에서 약 160 여 제품이 유통되 고 있고, 이러한 제품에서 다양한 부작용이 보고 되었다. 부작 용의 종류로는 부종(edema), 멍(bruising), 피부 트러블(skin disorderation), 감염(infection), 결절(nodular masses), 마비 (paresthesia), 혈관압박(vascular compromise) 등이 있다. 이 러한 부작용의 발생건수는 월당 약 $4.9 \pm 5.8$ 건인 것으로 조사 되었다(Funt \& Pavicic 2013; Funt \& Pavicic, 2015). 이 중 에서도 edema의 경우는 필러시술 후 6 개월 이내에 발생되는 급 성부종(acute edema)과 이후에 나타나는 지연성부종(delayed edema)으로 type I hypersensitivity 반응으로 인한 것으로 알 려져 있다(Lowe et al., 2005). 특히 이러한 부종의 부작용은 미용, 성형 특성상 민감한 불만사항으로 나타나고 있다. 일반적 으로 히알루론산 필러 시술 후의 edema의 발생은 원재료의 수 분 흡수성 특성으로부터 기인한 swelling 및 감염에 의한 염증 가능성이 있으나(Alijotas-Reig \& Garcia-Gimenez, 2008), delayed edema의 경우는 정확한 원인을 찾기가 어려운 것이 현 실이다.

만니톨(Mannitol)은 분자식 $\mathrm{C}_{6} \mathrm{H}_{14} \mathrm{O}_{6}$ 의 알코올 당류중의 하나 이며, 기능적으로는 체내 대사에 장시간을 요하고, 혈액 뇌관문 을 통과하지 않은 다당류로 혈중에 길게 존재하기 때문에 삼투압 활성물질로서의 작용이 있어서, 급성신부전이나 약물중독 시 배 설 촉진을 위한 이뇨제, 뇌압이나 안압 강하의 약물로 사용되고 있다(Barnett et al., 1948; Heiene \& Moe, 1998; Makimoto et al., 2018). 만니톨은 체내의 주사제로 현재 사용되고 있어서 안정성에 대하여 충분히 증명이 되어 있으므로 이 성분을 이용하 여 조직수복에 사용되는 히알루론산 필러에 대한 기능성 첨가소 재로 적합하다고 판단할 수 있다.

본 연구에서는 이러한 부종의 감소를 위하여 필러 제조공정상 사후 고압 습열 멸균을 고려하여 필러 고유의 점탄성 물성 변화 를 보호하며, 동시에 염증 및 부종 감소를 위한 첨가제를 혼합한 기능성 조직수복용 필러 소재를 구현하고자 하였다.

\section{Methods}

\section{1. 재료}

Hyaluronic acid (히알루론산) (MW: 1.2 MDa)는 Shiseido

\begin{tabular}{|c|c|}
\hline Solubilizing & $\begin{array}{c}\text { Hyaluronic acid/0.25 N NaOH solution } 1 \mathrm{~L} / 200 \mathrm{rpm} / \\
\text { room temperature }\end{array}$ \\
\hline Cross-linking & $\downarrow$ \\
\hline & \\
\hline Stabilizing & $25^{\circ} \mathrm{C} / 16-18 \mathrm{~h}$ \\
\hline \multicolumn{2}{|c|}{ BDDE $10.5 \mathrm{~mL} / 25^{\circ} \mathrm{C} / 40 \mathrm{~min}$} \\
\hline Dialysis & $25^{\circ} \mathrm{C} / 8$ days \\
\hline Grinding & $\downarrow$ \\
\hline & Mannitol (with or without)/PBS buffer \\
\hline Sterilization & $\downarrow$ \\
\hline
\end{tabular}

Figure 1. Manufacturing process scheme of BDDE-cross-linked hyaluronic acid gels.

Hyaluronic acid (10g) was completely dissolved in $1 \mathrm{~L} 0.25 \mathrm{M}$ $\mathrm{NaOH}$ solution. For crosslinking reaction, $10.5 \mathrm{~mL}$ of BDDE was added in hyaluronic alkaline solution, followed by immediate and vigorous stirring. The mixture was incubated at $25^{\circ} \mathrm{C}$ for $16-18$ $\mathrm{h}$ for stabilization. After the crosslinking reactions, the resulting crosslinked gel was purified by dialysis. Dialysis was performed against PBS for 8 days. The cross-linked gel was grinded with crusher, and then mixed with mannitol or PBS solution. The resulting cross-linked gels were sterilized at $121^{\circ} \mathrm{C}$ for $15 \mathrm{~min}$. BDDE, 1,4-butanediol diglycidyl ether; PBS, Phosphate-buffered saline.

(Japan)으로 부터 구입하였다. 가교제인 1,4-butanediol diglycidyl ether (MW: 202.25)는 Sigma-Aldrich (USA)에서 구입하였다. 히알루론산 용해를 위한 sodium hydroxide (MW: 40)는 Junsei Chemical Co. (Japan)에서 구입하였다. 투석을 위한 투석막(Cellu Sep T2)은 Membrane Filtration Products, Inc. (USA)로부터 구입하였다.

\section{2. 가교 히알루론산 겔 제조}

가교 히알루론산 겔의 제조는 먼저 용해, 가교반응, 가교안정 화, 투석 및 분쇄 공정의 순서로 하였다(Figure 1). 먼저 용해 공 정은 교반기에서 $200 \mathrm{rpm}$ 의 속도로 $0.25 \mathrm{~N}$ sodium hydroxide 수용액 $1 \mathrm{~L}$ 에 히알루론산을 첨가하여 $10 \%$ 히알루론산 수용액 $(\mathrm{w} / \mathrm{v})$ 을 제조하였다. 가교제인 1,4-butanediol diglycidyl ether (BDDE)을 완전히 용해된 히알루론산 수용액에 $10.5 \mathrm{~mL}$ (1.05\%)을 넣어 $40 \mathrm{~min}$ 간 잘 혼합한 후, 반응물을 일정한 규격 $(132 \mathrm{~mm} \times 80 \mathrm{~mm})$ 의 가교조에 담아 $25^{\circ} \mathrm{C}$ 로 유지하면서 $16-$ $18 \mathrm{~h}$ 동안 가교를 시켰다. 가교 후 형성된 BDDE cross-linked 히알루론산 겔(가교 히알루론산 겔)을 투석막(Cellu Sep T2)에 담아 8일간 동안 상온에서 투석을 실시하였다. 투석이 완료된 가 교 히알루론산 겔은 분쇄기(GM-300)에 담아 분쇄하였다. 분쇄 는 PBS 완충액 혹은 mannitol과 PBS 완충액과 함께 첨가하면 서 최종적으로 mannitol이 혼합된 가교 히알루론산 겔 $(1 \%, 5 \%$, 
$20 \%$ mannitol/가교 히알루론산 겔)을 제조하였다.

\section{3. 유변학적 물성 측정}

가교 히알루론산 겔의 유변학적 물성 측정을 위하여 사용된 레 오미터(rheometer)의 측정조건으로 플레이트는 지름 $20 \mathrm{~mm}$ 의 평판형(parallel plate type)으로, 플레이트의 간격(gap)은 $2000 \mu \mathrm{m}$ 및 분석 온도 $25^{\circ} \mathrm{C}$ 로 장비는 Malvern instruments (KINEXUS Pro+, USA)을 이용하여 측정하였다. 유변학적 특 성은 일정한 스트레인 진폭(strain frequency, $\gamma$ )을 유지하면서 시간 $(\mathrm{t})$ 에 따라 각주파수 $\omega=\omega(\mathrm{t})$ 로 점차 증가하는 $\gamma=\gamma_{0} \sin \omega \mathrm{t}$ 의 정현적 진동전단변형을 시료에 부가하여 그 응답을 측정하였 다. 이때 각주파수는 $\omega=0.025-10 \mathrm{rad} / \mathrm{s}$ 까지 대수 스케일로 단 계적으로 증가시켰다. 이로부터 탄성(storage modulus, $\mathrm{G}^{\prime}$ ), 점성(loss modulus, $\left.G^{\prime \prime}\right)$, 복소점도(complex viscosity, $G^{*}$ ) 및 phase angle $\left(^{0}\right)$ 을 측정하였다.

\section{Oxidative stress 억제 효과}

라디칼 반응에 의한 가교 히알루론산 겔을 분해시키기 위한 방 법으로 잘 알려진 과산화수소(hydrogen peroxide, $\mathrm{H}_{2} \mathrm{O}_{2}$ )를 사 용하였다(Conrozier et al., 2014; Jeong, 2017; Šoltés et al., 2007). 가교 히알루론산 겔 및 mannitol 혼합 가교 히알루론산 겔에 oxidative stress을 형성시키기 위하여 $30 \%$ 과산화수소를 사용하여 가교 히알루론산 겔과 혼합하여 과산화수소의 최종반 응농도 $2.7 \%$ 가 되도록 하여 oxidative stress을 유발시켰다. 과 산화수소와 혼합된 가교 히알루론산 겔은 레오메타를 이용하여 유변학적 특성을 측정하였다. 과산화수소의 첨가는 레오메타을 이용하여 유변학적 물성 측정 시간을 고려하여 레오메타의 측정 바로 직전 $5 \mathrm{~min}$ 전에 과산화수소를 첨가하여 빠르게 교반한 후 에 측정하였다.

\section{Mannitol 혼합에 의한 가교 히알루론산 겔의 열안정성}

Mannitol 혼합에 의한 가교 히알루론산 겔의 가열 시 형성되 는 radical에 의한 가교 히알루론산 겔의 구조적 파괴 정도를 측 정하였다. 가교 히알루론산 겔의 열안정성을 위한 열은 $121^{\circ} \mathrm{C}$ 의 고압습열멸균(autoclave) 조건으로 하였다. Mannitol의 농도 별로 제조한 가교 히알루론산 겔을 pre-fliled syringe에 $1 \mathrm{~mL}$ 씩 충전하여 $121^{\circ} \mathrm{C} / 15 \mathrm{~min}$ 고압습열멸균기로 열을 가한 후, 각 각의 시료 $(0 \%, 0.5 \% 1 \%, 2.5 \%, 5 \%$ mannitol/가교 히알루론산 겔)에 대하여 유변학적 특성의 변화를 측정하였다.

\section{6. 부종 억제 측정을 위한 이뇨 작용 동물 시험}

삼투압으로 발생되는 부종은 가교 겔 자체로 정맥투여가 불 가능하여 겔 첨가되는 mannitol의 농도로 이뇨 효과를 측정 하여 평가하였다. 즉, 이뇨 작용이 활발한 경우는 삼투압으로
부터 발생되는 부종억제 효과가 있는 것으로 평가하였다. 시 험 전일부터 실험동물은 단식시켰으나 물은 공급하였다. 마취 된 개(pentobarbital sodium을 $35 \mathrm{mg} / \mathrm{kg}$. i.v.)는 동물고정 대에 배위로 고정하여 호흡을 용이하게 하기 위하여 기도 내에 endotracheal tube롭 넣어서 고정하고 주입액의 주입과 정맥 내외 mannitol의 투여는 상지정맥을 이용하였으며 주입액의 주 입은 peristaltic pump을 사용하였다. 집뇨는 고정한 개를 정 중절개하여 양측수뇨관에 삼입고정한 polyethylene관( $\mathrm{PE}$ 관) 을 통하여 하였다. Clearance는 clearance 물질(creatinine, $\mathrm{PAH})$ 을 일정한 혈중농도에 일시에 도달하도록 초회 량을 투여 한후 곧이어 뇨중에 배설되는 만큼 주입액에 첨가하여 계속 주 입하였으며 매clearance 중간에 대퇴동맥에 heparine-saline 으로 채워서 삽입 고정하여둔 $\mathrm{PE}$ 관을 통하여 채혈하여 곧 원침 한 다음 혈장을 분리하여 냉장고에 보관하였다가 뇨와 함께 분 석에 사용하였다. Creatinine은 Peters \& Van Slyke (1944) 의 방법, $\mathrm{PAH}$ 는 Smith et al. (1945)의 방법을 준하였고 $\mathrm{Na}^{+}$ 과 $\mathrm{K}^{+}$은 flame photometer (Models PFP7, Jenway, UK)로 osmolarity는 osmometer (3250; Fisher scientific lab, UK) 로 측정하였다. 본 실험을 위하여 동물윤리위원회의 승인을 득하 였다(KJAEC-2018207).

\section{7. 통계분석}

실험결과는 평균 및 표준편차로 나타내었으며, 이를 위한 통계 학적 검증은 Student's paired $t$-test로 하였다.

\section{Results and Discussion}

\section{1. 가교 히알루론산 겔의 유변학적 성질의 변화}

Mannitol 첨가가 가교 히알루론산 겔의 탄성 $\left(G^{\prime}\right)$ 및 점성 $\left(G^{\prime \prime}\right)$ 에 미치는 영향은 Figure 2 와 같았다.

가교 히알루론산 겔에 있어서mannitol의 첨가는 농도와 상관 없이 측정된 모든 frequency $(0.1-10 \mathrm{~Hz})$ 범위에서 증가하는 경향이 나타났다. G'에서 $0.1 \mathrm{~Hz}$ frequency의 값은 mannitol의 첨가 농도에 따라서 큰 변화는 없었다. Mannitol $0 \%, 1 \%, 5 \%$ 및 $20 \%$ 첨가군에서 $\mathrm{G}^{\prime}$ 의 값은 $0.1 \mathrm{~Hz}$ 에서 각각 $280.5,283.0$, 283.1 및 $291.5 \mathrm{~Pa}$ 로 측정이 되었다. $20 \%$ 첨가군은 약간의 $\mathrm{G}^{\prime}$ 의 상승을 가져왔으나, 나머지 첨가군 대비 유의적으로 증가된 값은 아닌 것으로 평가되었다.

한편 $\mathrm{G}^{\prime \prime}$ 의 경우는 mannitol의 첨가농도의 증가에 따라서 $0.1 \mathrm{~Hz}$ 에서 각각 $38.9,33.1,33.1$ 및 $39.8 \mathrm{~Pa}$ 로 나타났으며, mannitol $0 \%$ 와 $20 \%$ 에서 모두 나머지 2 군 대비 다른 값이 나타 났으나 유의적인 차이는 없었다.

Frequency가 10 배 정도 증가된 시점 인 $1 \mathrm{~Hz}$ 에서의 $\mathrm{G}^{\prime \prime}$ 의 경 


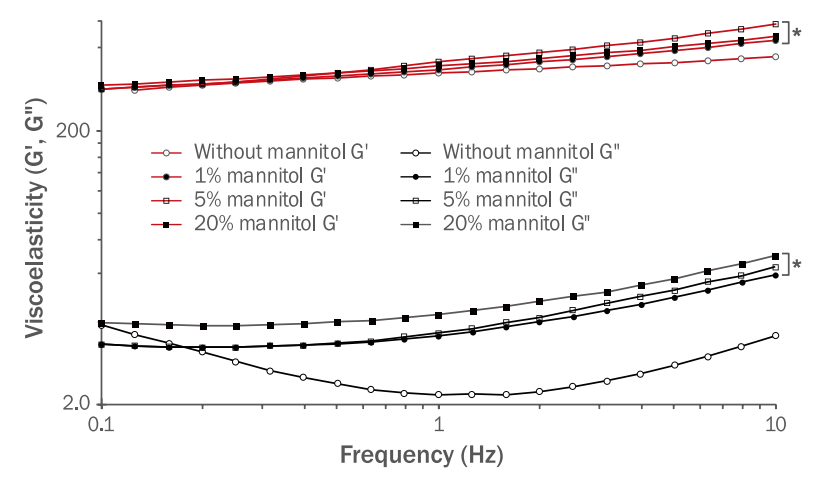

Figure 2. Dynamic rheological properties of cross-linked HA gel mixture with and without mannitol.

Rheological analyses were performed under continuous and oscillatory flow conditions using a rotational rheometer (Kinexus DSR; Malvern, USA) with a plate-plate geometry (fixed $2 \mathrm{~mm}$ gap) at $25^{\circ} \mathrm{C}$. The viscoelastic properties, G' and G" were measured at fixed oscillation amplitudes within each material's linear viscoelastic region by varying the oscillation frequency (0.025$10 \mathrm{rad} / \mathrm{s})$. Results significantly different from those of the control group ( $\left.{ }^{*} p<0.05\right)$. G' storage modulus; G”, loss modulus.

우, mannitol이 첨가된 군과 그렇지 않은 군에서 극명한 $\mathrm{G}^{\prime \prime}$ 의 차이를 나타내었다. Mannitol이 첨가되는 않은 군에서는 21.6 $\mathrm{Pa}$ 로 초기 $\mathrm{Hz}$ 값은 $38.9 \mathrm{~Pa}$ 대비 감소하였으며, mannitol이 첨 가된 군은 농도와 상관없이 커다란 변화없이 유지되는 경향을 보 였으며, 구체적으로 $0.1 \mathrm{~Hz}$ 와 $1 \mathrm{~Hz}$ 사이에서 서서히 증가되는 경향을 보였으나 유의적인 증가로는 볼 수 없었다.

Frequency가 초기 대비 100 배 증가된 $10 \mathrm{~Hz}$ 에서는 G' 및 G" 모두 mannitol이 첨가된 군과 첨가되지 않은 군의 차이는 극명 하게 나타났다. $\mathrm{G}^{\prime}$ 의 경우, mannitol의 농도 의존적 첨가 $(0 \%$, $1 \%, 5 \%$ 및 $20 \%$ )에 따라서 $10 \mathrm{~Hz}$ 에서 각각 $378.3,427.4$, 487.2 및 $440.2 \mathrm{~Pa}$ 로 측정되었으며, mannitol이 첨가된 군과 첨가되지 않은 군에서는 $0.1 \mathrm{~Hz}$ 및 $1 \mathrm{~Hz}$ 대비 모두 유이적으로 증가하였다.

한편 mannitol 첨가 농도에 따라서는 농도 의존적 효과는 볼 수 없었다. $\mathrm{G}^{\prime \prime}$ 의 경우는 mannitol의 첨가 농도 $0 \%, 1 \%, 5 \%$ 및

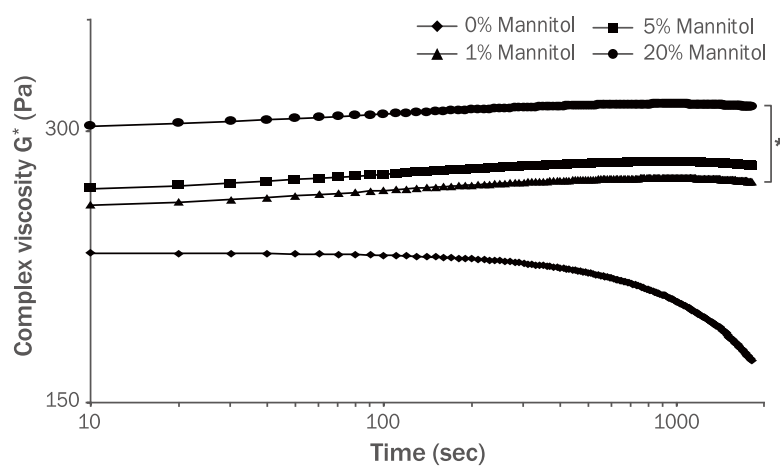

Figure 3. Change of complex viscosity $\left(G^{*}\right)$ of cross-linked gel mixtures with and without mannitol by hydroxyl radicals.

Cross-linked gels with and without added mannitol were subjected to oxidative stress, generated by adding hydrogen peroxide (30\%) at a final concentration of $2.7 \%(\mathrm{v} / \mathrm{v})$. The complex viscosity was measured using a plate-plate rheometer at $25^{\circ} \mathrm{C}$, at a frequency of $1 \mathrm{~Hz}$. Results significantly different from those of the control group $\left({ }^{*} p<0.05\right)$.

$20 \%$ 에 따라서 각각 $35.5,59.5,63.5$ 및 $69.6 \mathrm{~Pa}$ 로 농도 의존 적이며 유의 있게 증가하였다. 특히 mannitol이 첨가된 군과 첨 가되지 않은 군의 차이는 확실하게 나타났다. Mannitol은 항산 화 효과가 우수한 polyol 계열의 ROS scavenger로 알려져 있다. 이러한 항산화 효능이 히알루론산 가교 겔이 $\mathrm{G}^{\prime}$ 및 $\mathrm{G}^{\prime \prime}$ 에 안정화를 가져오는 것으로 사료된다.

\section{2. 가교 히알루론산 겔의 산화 안정성}

히알루론산의 화학적인 특성으로 산화에 의하여 분자량이 감 소되어 점도가 떨어진다. 따라서 산화로 부터의 보호는 분자량의 감소를 막아 고유의 점도를 유지해 줄 수 있다. 가교된 히알루론 산 겔의 산화로부터 보호효과를 위하여 첨가된 mannitol의 산화 안정성을 측정하였으며, 그 결과는 Figure 3 및 Table 1와 같았 다. 가교 히알루론산 겔의 과산화수소 $\left(\mathrm{H}_{2} \mathrm{O}_{2}\right)$ 에 의한 산화 안정성 의 평가는 가교 겔의 유변학적 요소인 탄성 $\left(\mathrm{G}^{\prime}\right)$, 점성 $\left(\mathrm{G}^{\prime \prime}\right)$ 및 복소 점도 $\left(\mathrm{G}^{*}\right)$ 로 평가하였다.

Table 1. Changes in the rheological properties (G', G") of cross-linked gel mixtures with and without mannitol due to hydroxyl radicals

\begin{tabular}{|c|c|c|c|c|c|}
\hline & Time (s) & 10 & 120 & 1,000 & 1,800 \\
\hline \multirow{2}{*}{ 0\% Mannitol } & $\mathrm{G}^{\prime}(\mathrm{Pa})$ & 242.6 & 241.1 & 217.3 & 190.0 \\
\hline & $\mathrm{G}^{\prime \prime}(\mathrm{Pa})$ & 43.0 & 42.5 & 40.3 & 38.8 \\
\hline \multirow{2}{*}{ 1\% Mannitol } & $\mathrm{G}^{\prime}(\mathrm{Pa})$ & 243.7 & $254.9^{*}$ & $262.5^{*}$ & $259.9^{*}$ \\
\hline & $\mathrm{G}^{\prime \prime}(\mathrm{Pa})$ & $48.3^{*}$ & $45.7^{*}$ & $45.0^{*}$ & $46.0^{*}$ \\
\hline \multirow{2}{*}{$5 \%$ Mannitol } & $\mathrm{G}^{\prime}(\mathrm{Pa})$ & $253.7^{*}$ & $264.9^{*}$ & $272.5^{*}$ & $269.9^{*}$ \\
\hline & G" (Pa) & $53.3^{*}$ & $50.7^{*}$ & $50.0^{*}$ & $51.0^{*}$ \\
\hline 20\% Mannitol & $\begin{array}{l}\mathrm{G}^{\prime}(\mathrm{Pa}) \\
\mathrm{G}^{\prime \prime}(\mathrm{Pa})\end{array}$ & $\begin{array}{r}293.7^{*} \\
79.3^{*}\end{array}$ & $\begin{array}{r}304.9^{*} \\
76.7^{*}\end{array}$ & $\begin{array}{r}312.5^{*} \\
76.0^{*}\end{array}$ & $\begin{array}{r}309.9^{*} \\
77.0^{*}\end{array}$ \\
\hline
\end{tabular}

Results significantly different from those of the control group ( $\left.{ }^{*} p<0.05\right)$. 

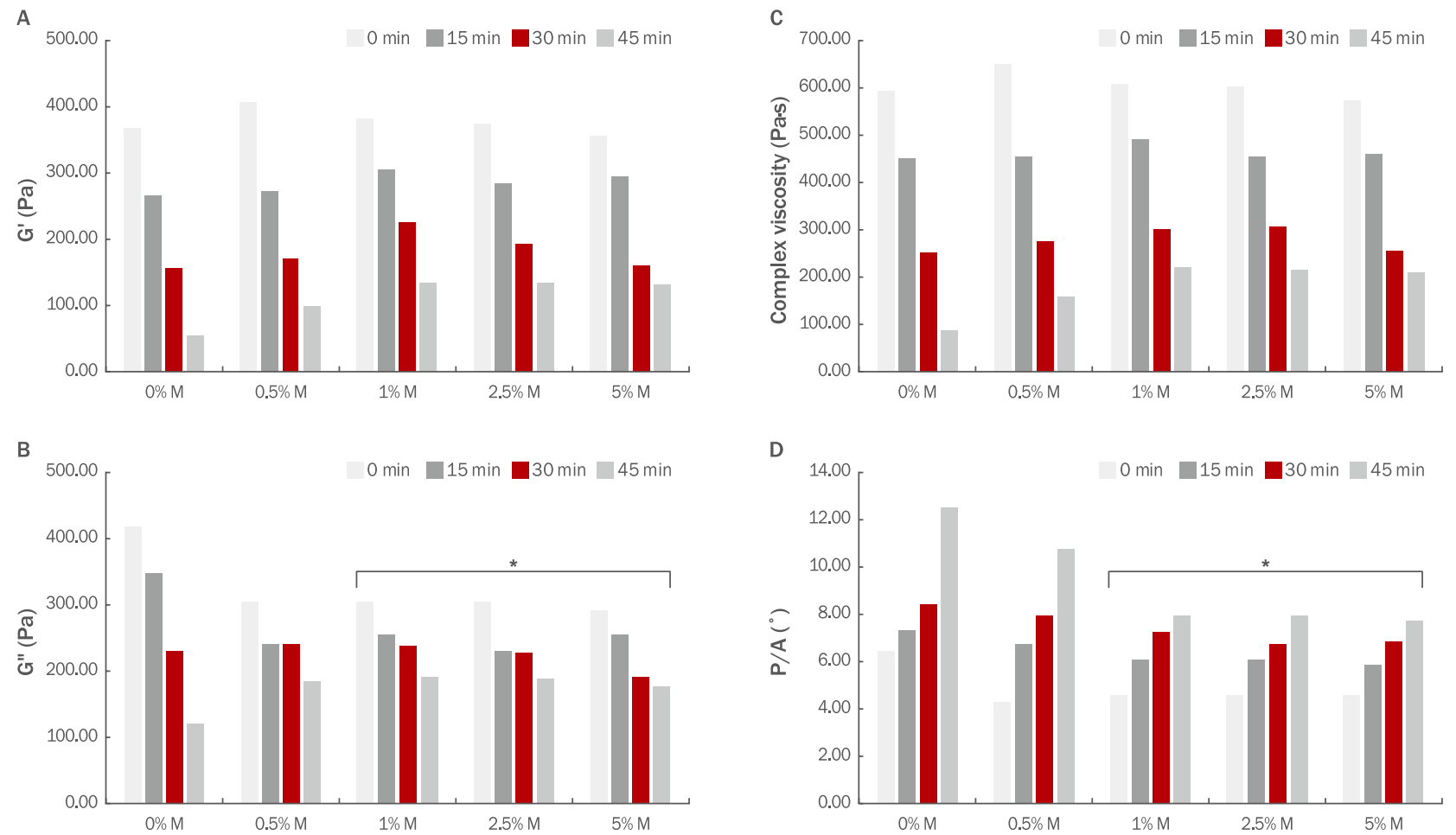

Figure 4. Thermal stability of cross-linked gel mixtures with and without mannitol.

(A) G', (B) G", (C) Complex modulus, (D) P/A. The complex viscosity was measured using a plate-plate rheometer at $25^{\circ} \mathrm{C}$, at a frequency of $1 \mathrm{~Hz}$. Results significantly different from those of the control group $\left({ }^{*} p<0.05\right)$. G' storage modulus; G”, loss modulus; $P / A$, phase angle.

Mannitol이 첨가되는 않은 군에서는 과산화수소의 첨가에 의 하여 $\mathrm{G}^{\prime}$ 및 $\mathrm{G}^{\prime \prime}$ 모두 과산화수소에 의한 노출 시간이 지남에 따 라서 유의적으로 감소하였다. $\mathrm{G}^{\prime}$ 및 $\mathrm{G}^{\prime \prime}$ 의 측정 초기 $(10 \mathrm{~s})$ 의 값 은 각각 242.6 과 $43.0 \mathrm{~Pa}$ 로 나타났고, 측정 최종 $(1,800 \mathrm{~s})$ 값은 각각 190.0 및 $38.8 \mathrm{~Pa}$ 로 나타났으며 감소율은 각각 $21.7 \%$ 및 $9.7 \%$ 로 $\mathrm{G}^{\prime}$ 값이 $\mathrm{G}^{\prime \prime}$ 대비 많이 감소하는 것으로 나타났다.

Mannitol 첨가군에서는 첨가한 농도에 따른 농도 의존적인 효 과는 나타나지 않았다. 특히 $\mathrm{G}^{\prime}$ 값의 경우는 mannitol 첨가에 의 하여 과산화수소에 의한 노출 시간이 경과하여도 감소가 관찰 되지 않았으며, $\mathrm{G}^{\prime \prime}$ 의 경우는 mannitol 첨가량에 따라서 $\mathrm{G}^{\prime \prime}$ 의 감소에 저항성을 나타내는 경향을 보였으나 유의차는 없었다. Mannitol 첨가의 유무에 따라서는 $G^{\prime}$ 및 $G^{\prime \prime}$ 모두 유의적인 효과 가 나타났다(Table 1).

$G^{\prime}$ 및 $G^{\prime \prime}$ 의 변화를 복합적으로 반영하는 것이 $G^{*}$ 인데, $G^{*}$ 역시 $\mathrm{G}^{\prime}$ 및 $\mathrm{G}^{\prime \prime}$ 의 변화와 같이 mannitol의 첨가 유무에 따라서 산화적 스트레스에 대한 저항성이 유의하게 나타났다. 또한 mannitol 의 첨가 농도에 따라서 농도 의존적인 효과가 나타났다(Figure 3). Conrozier et al. (2014)의 연구내용에서 mannitolo이 3.5\% 의 농도로 첨가된 히알루론산 관절주사제와 mannitol이 첨가되 지 않은 기존의 관절주사제에 의한 산화 스트레스에 대한 관절주
사제의 유변학적인 변화를 측정한 결과, mannitolo이 첨가된 관 절주사제가 산화에 대한 저항이 나타났다. 본 실험의 결과 역시 Conrozier et al. (2014)의 연구 결과와 일치하는 것으로 판단하 였다.

\section{3. 가교 히알루론산 겔의 열안정성}

가교 히알루론산 겔의 제조 후 최종 제품을 위해서는 멸균을 시켜야 한다. 멸균의 방법으로는 고압습열멸균을 실시하게 되며, 이때에 열에 의한 산화 스트레스가 발생하게 되어 가교 겔의 분 해를 가져오게 된다. 이러한 분해는 곧바로 유변학적 물성에 영 향을 주어 탄성 $\left(\mathrm{G}^{\prime}\right)$, 점성 $\left(\mathrm{G}^{\prime \prime}\right)$, 복소점도 $\left(\mathrm{G}^{*}\right)$ 및 phase angle $(\mathrm{P} / \mathrm{A})$ 에 변화를 가져오는데, mannitol 첨가에 의하여 이와 같은 유변학적 물성 변화에 어떠한 영향을 주는지 측정하였다. 일반적 으로 히알루론산은 열에 대하여 불안정하며, 가교된 히알루론산 겔 역시 열에 불안정 할 수밖에 없다(Caspersen et al., 2014). $121^{\circ} \mathrm{C}$ 의 고압습열멸균에서 가교 히알루론산 겔은 가열로 인하여 가열 전의 유변학적인 물성의 붕괴를 가져왔다(Figure 4).

가열 시간이 증가함에 따라서 $\mathrm{G}^{\prime}, \mathrm{G}^{\prime \prime}$ 및 $\mathrm{G}^{*}$ 의 감소와 $\mathrm{P} / \mathrm{A}$ 의 증가를 가져와 겔상의 구조가 가열 스트레스로 인하여 붕괴되 는 것으로 평가되었다. 즉, $\mathrm{G}^{\prime}$ 의 경우는 가열 시간 $15 \mathrm{~min}, 30$ 
$\min$ 및 최종 $45 \mathrm{~min}$ 까지 측정한 결과, 최초 $370.0 \mathrm{~Pa}$ 에서 각각 의 물성 값은 $267.4 \mathrm{~Pa}$ (감소율 $24 \%$ ), $155.2 \mathrm{~Pa}$ (감소율 $58 \%$ ) 및 $54.5 \mathrm{~Pa}$ (감소율 $85 \%$ )이었고(Figure $4 \mathrm{~A}$ ), G"값은 변화는 최초 $41.7 \mathrm{~Pa}$ 에서 각각 $34.6 \mathrm{~Pa}$ (감소율 $17 \%$ ), $23.0 \mathrm{~Pa}$ (감소 율 $45 \%$ ) 및 $12.1 \mathrm{~Pa}$ (감소율 $71 \%$ )(Figure $4 \mathrm{~B}), \mathrm{G}^{*}$ 값은 최초 $592.5 \mathrm{~Pa}$ 에서 각각 $451.1 \mathrm{~Pa}$ (감소율 $24 \%$ ), $249.7 \mathrm{~Pa}$ (감소 율 $58 \%$ ) 및 $88.9 \mathrm{~Pa}$ (감소율 $85 \%$ )(Figure $4 \mathrm{C}$ ), $\mathrm{P} / \mathrm{A}$ 값은 최초 $6.4^{\circ}$ 에서 각각 $7.4^{\circ}, 8.4^{\circ}$ 및 $12.5^{\circ}$ 로 나타났다(Figure 4D).

Mannitol의 첨가에 의하여 $\mathrm{G}^{\prime}, \mathrm{G}^{\prime \prime}, \mathrm{G}^{*}$ 및 $\mathrm{P} / \mathrm{A}$ 의 변화에 영향 을 미쳤다. 가교 겔에 대하여 mannitol의 첨가는 가열에 의한 스 트레스로부터 가교 구조의 안정화를 가져 다 주는 것으로 평가되 었다.

$0.5 \%$ mannitol 첨가 군의 경우, $\mathrm{G}^{\prime}$ 값의 가열시간 $(15 \mathrm{~min}, 30$ $\min$ 및 $45 \mathrm{~min}$ )에 따른 변화는 최초 $407.9 \mathrm{~Pa}$ 에서 각각 272.6
$\mathrm{Pa}$ (감소율 $33 \%$ ), $170.9 \mathrm{~Pa}$ (감소율 $58 \%$ ) 및 $98.2 \mathrm{~Pa}$ (감소율 $76 \%$ )이었고(Figure $4 \mathrm{~A}$ ), G"값은 최초 $30.5 \mathrm{~Pa}$ 에서 각각 24.1 $\mathrm{Pa}$ (감소율 $21 \%$ ), $24.0 \mathrm{~Pa}$ (감소율 $21 \%$ ) 및 $18.6 \mathrm{~Pa}$ (감소율 $39 \%$ )(Figure $4 \mathrm{~B}$ ), $\mathrm{G}^{*}$ 값은 최초 651.0 에서 각각 $456.5 \mathrm{~Pa}$ (감 소율 $30 \%$ ), $274.7 \mathrm{~Pa}$ (감소율 $58 \%$ ) 및 $159.0 \mathrm{~Pa}$ (감소율 76\%) (Figure $4 \mathrm{C}), \mathrm{P} / \mathrm{A}$ 값은 최초 $4.3^{\circ}$ 에서 각각 $6.7^{\circ}, 8.0^{\circ}$ 및 $10.7^{\circ}$ 로 나타났다(Figure 4D).

$1 \%$ mannitol 첨가 군의 경우, $\mathrm{G}^{\prime}$ 값의 가열시간에 따른 변화 는 최초 $382.5 \mathrm{~Pa}$ 에서 각각 $306.1 \mathrm{~Pa}$ (감소율 $20 \%$ ), 226.0 Pa (감소율 $41 \%$ ) 및 $137.4 \mathrm{~Pa}$ (감소율 $64 \%$ )이었고(Figure 4A), $\mathrm{G}$ "값은 최초 $30.6 \mathrm{~Pa}$ 에서 각각 $25.4 \mathrm{~Pa}$ (감소율 $17 \%$ ), 23.7 $\mathrm{Pa}$ (감소율 $23 \%$ ) 및 $19.1 \mathrm{~Pa}$ (감소율 $37 \%$ )(Figure $4 \mathrm{~B}$ ), $\mathrm{G}^{*}$ 값 은 최초 610.7 에서 각각 $489.7 \mathrm{~Pa}$ (감소율 $20 \%$ ), $298.5 \mathrm{~Pa}$ (감 소율 $51 \%$ ) 및 $220.8 \mathrm{~Pa}$ (감소율 $64 \%$ )(Figure $4 \mathrm{C}$ ), P/A값은 최

Table 2. Effect of mannitol injections on renal function in the dog model

\begin{tabular}{|c|c|c|c|c|}
\hline \multirow{2}{*}{ Treatment } & \multirow{2}{*}{ Parameter } & \multicolumn{3}{|c|}{ Time since mannitol injection } \\
\hline & & $0-30 \mathrm{~min}$ & $0-60 \mathrm{~min}$ & $0-120 \mathrm{~min}$ \\
\hline \multirow{8}{*}{ Control } & Urine Vol (mL/min) & $6.8 \pm 0.8$ & $13.9 \pm 0.9$ & $19.1 \pm 3$ \\
\hline & $\mathrm{GFR}(\mathrm{mL} / \mathrm{min})$ & $44.1 \pm 2.6$ & $44.2 \pm 4.5$ & $44.1 \pm 3.8$ \\
\hline & $\mathrm{RPF}(\mathrm{mL} / \mathrm{min})$ & $91.1 \pm 4.1$ & $100.1 \pm 11.3$ & $105 \pm 10.6$ \\
\hline & $\operatorname{Cosm}(\mathrm{mL} / \mathrm{min})$ & $4.35 \pm 0.3$ & $4.79 \pm 0.7$ & $5.03 \pm 1.1$ \\
\hline & $\mathrm{C}_{\mathrm{H} 2 \mathrm{O}}(\mathrm{mL} / \mathrm{min})$ & $-1.03 \pm 0.1$ & $-1.56 \pm 0.1$ & $-1.33 \pm 0.4$ \\
\hline & $\mathrm{E}_{\mathrm{Na}}(\mu \mathrm{Eq} / \min )$ & $384.5 \pm 26.1$ & $422.9 \pm 24.1$ & $444.1 \pm 30.1$ \\
\hline & $\mathrm{E}_{\mathrm{K}}(\mu \mathrm{Eq} / \min )$ & $46.1 \pm 2.6$ & $50.3 \pm 6.7$ & $52.8 \pm 6.1$ \\
\hline & MAP (mmHg) & $139.3 \pm 3.6$ & $153.2 \pm 11.8$ & $150.2 \pm 19.7$ \\
\hline \multirow{8}{*}{ 1\% Mannitol } & Urine Vol (mL/min) & $7.1 \pm 0.4$ & $14.3 \pm 1.2$ & $19.5 \pm 1.8$ \\
\hline & GFR (mL/min) & $45.9 \pm 5.1$ & $45.1 \pm 6.5$ & $45.0 \pm 8.1$ \\
\hline & $\mathrm{RPF}(\mathrm{mL} / \mathrm{min})$ & $94.7 \pm 9.4$ & $102.1 \pm 14.2$ & $107.1 \pm 10.5$ \\
\hline & $\operatorname{Cosm}(\mathrm{mL} / \mathrm{min})$ & $4.5 \pm 0.7$ & $4.9 \pm 1.1$ & $4.9 \pm 1.4$ \\
\hline & $\mathrm{C}_{\mathrm{H} 2 \mathrm{O}}(\mathrm{mL} / \mathrm{min})$ & $-1.1 \pm 0.1$ & $-1.1 \pm 0.1$ & $-1.2 \pm 0.1$ \\
\hline & $\mathrm{E}_{\mathrm{Na}}(\mu \mathrm{Eq} / \mathrm{min})$ & $399.9 \pm 29.2$ & $431.4 \pm 28.5$ & $453.0 \pm 19.6$ \\
\hline & $\mathrm{E}_{\mathrm{K}}(\mu \mathrm{Eq} / \min )$ & $47.9 \pm 3.7$ & $51.3 \pm 4.8$ & $53.9 \pm 5.1$ \\
\hline & MAP (mmHg) & $144.9 \pm 10.4$ & $156.3 \pm 9.9$ & $153.2 \pm 11.4$ \\
\hline \multirow{8}{*}{ 5\% Mannitol } & Urine Vol (mL/min) & $8.4 \pm 0.8^{*}$ & $16.2 \pm 0.6^{*}$ & $21.3 \pm 3.9$ \\
\hline & $\operatorname{GFR}(\mathrm{mL} / \mathrm{min})$ & $50.5 \pm 2.9^{*}$ & $47.8 \pm 3.5$ & $49.5 \pm 4.7$ \\
\hline & $\mathrm{RPF}(\mathrm{mL} / \mathrm{min})$ & $104.2 \pm 9.9$ & $108.2 \pm 2.4$ & $117.8 \pm 5.5$ \\
\hline & $\operatorname{Cosm}(\mathrm{mL} / \mathrm{min})$ & $5.0 \pm 0.7$ & $5.2 \pm 0.8$ & $5.4 \pm 0.5$ \\
\hline & $\mathrm{C}_{\mathrm{H} 2 \mathrm{O}}(\mathrm{mL} / \mathrm{min})$ & $-1.2 \pm 0.1$ & $-1.2 \pm 0.1$ & $-1.3 \pm 0.1$ \\
\hline & $\mathrm{E}_{\mathrm{Na}}(\mu \mathrm{Eq} / \min )$ & $439.9 \pm 24.1$ & $457.2 \pm 30.5$ & $498.3 \pm 22.2$ \\
\hline & $\mathrm{E}_{\mathrm{K}}(\mu \mathrm{Eq} / \mathrm{min})$ & $52.7 \pm 6.3$ & $54.4 \pm 3.7$ & $59.2 \pm 8.2$ \\
\hline & MAP (mmHg) & $159.4 \pm 9.6$ & $165.6 \pm 11.5$ & $168.5 \pm 10.2$ \\
\hline \multirow{8}{*}{ 20\% Mannitol } & Urine Vol (mL/min) & $47.7 \pm 2.9^{*}$ & $85.2 \pm 2.5^{*}$ & $107.2 \pm 21.3^{*}$ \\
\hline & GFR $(\mathrm{mL} / \mathrm{min})$ & $50.5 \pm 2.9^{*}$ & $47.8 \pm 3.5^{*}$ & $49.5 \pm 4.7^{*}$ \\
\hline & $\mathrm{RPF}(\mathrm{mL} / \mathrm{min})$ & $177.2 \pm 30.3^{*}$ & $227.3 \pm 28.4^{*}$ & $271.0 \pm 30.7^{*}$ \\
\hline & $\operatorname{Cosm}(\mathrm{mL} / \mathrm{min})$ & $8.5 \pm 0.7^{*}$ & $10.9 \pm 0.4^{*}$ & $12.5 \pm 1.1^{*}$ \\
\hline & $\mathrm{C}_{\mathrm{H} 2 \mathrm{O}}(\mathrm{mL} / \mathrm{min})$ & $-2.0 \pm 0.1^{*}$ & $-2.4 \pm 0.1^{*}$ & $-1.6 \pm 0.1^{*}$ \\
\hline & $\mathrm{E}_{\mathrm{Na}}(\mu \mathrm{Eq} / \min )$ & $483.9 \pm 40.2^{*}$ & $503.0 \pm 20.6^{*}$ & $548.1 \pm 17.8^{*}$ \\
\hline & $\mathrm{E}_{\mathrm{K}}(\mu \mathrm{Eq} / \mathrm{min})$ & $58.0 \pm 4.1^{*}$ & $59.8 \pm 3.3$ & $65.2 \pm 5.6^{*}$ \\
\hline & $\operatorname{MAP}(\mathrm{mmHg})$ & $270.9 \pm 20.1^{*}$ & $281.6 \pm 17.3^{*}$ & $286.5 \pm 19.4^{*}$ \\
\hline
\end{tabular}

Data show means \pm S.D. of 6 experiments. Vol, urine flow rate; GFR, glomerular filtration rate, calculated from the creatinine clearance; $\mathrm{RPF}$, renal plasma flow, calculated from the $\mathrm{p}$-aminohippuric acid clearance; Cosm and $\mathrm{C}_{\mathrm{H} 20}$, osmolar substance and free water clearances, respectively; $\mathrm{E}_{\mathrm{Na}}$ and $\mathrm{E}_{\kappa}$, amounts of sodium and potassium excreted in urine, respectively; MAP, mean arterial pressure. Results significantly different from those of the control group $\left({ }^{*} p<0.05\right) ;$ S.D., standard deviation. 
초 $4.6^{\circ}$ 에서 각각 $6.1^{\circ}, 7.3^{\circ}$ 및 $7.9^{\circ}$ 로 나타났다(Figure 4D).

$2.5 \%$ mannitol 첨가 군의 경우, $\mathrm{G}^{\prime}$ 값의 가열시간에 따른 변화 는 최초 $377.7 \mathrm{~Pa}$ 에서 각각 $283.7 \mathrm{~Pa}$ (감소율 $25 \%$ ), $191.0 \mathrm{~Pa}$ (감소율 49\%) 및 $191.0 \mathrm{~Pa}$ (감소율 64\%)이었고(Figure 4A), $\mathrm{G}^{\prime \prime}$ 값은 최초 $30.5 \mathrm{~Pa}$ 에서 각각 $22.9 \mathrm{~Pa}$ (감소율 $25 \%$ ), $22.6 \mathrm{~Pa}$ (감소율 $26 \%$ ) 및 $18.7 \mathrm{~Pa}$ (감소율 $39 \%$ )(Figure $4 \mathrm{~B}$ ), $\mathrm{G}^{*}$ 값은 최초 603.0 에서 각각 $453.8 \mathrm{~Pa}$ (감소율 $25 \%$ ), $306.1 \mathrm{~Pa}$ (감소 율 49\%) 및 $215.9 \mathrm{~Pa}$ (감소율 64\%)(Figure 4C), P/A값은 최초 $4.6^{\circ}$ 에서 각각 $6.0^{\circ}, 6.8^{\circ}$ 및 $7.9^{\circ}$ 로 나타났다(Figure 4D).

$5 \%$ mannitol 첨가 군의 경우, $\mathrm{G}^{\prime}$ 값의 가열시간에 따른 변화 는 최초 $357.7 \mathrm{~Pa}$ 에서 각각 $296.9 \mathrm{~Pa}$ (감소율 $17 \%$ ), $158.3 \mathrm{~Pa}$ (감소율 $56 \%$ ) 및 $131.5 \mathrm{~Pa}$ (감소율 $63 \%$ )이었고(Figure 4A), $\mathrm{G}^{\prime \prime}$ 값은 최초 $28.9 \mathrm{~Pa}$ 에서 각각 $25.4 \mathrm{~Pa}$ (감소율 $12 \%$ ), 19.1 $\mathrm{Pa}$ (감소율 $34 \%$ ) 및 $17.7 \mathrm{~Pa}$ (감소율 $39 \%$ )(Figure $4 \mathrm{~B}$ ), $\mathrm{G}^{*}$ 값 은 최초 571.1 에서 각각 $462.0 \mathrm{~Pa}$ (감소율 $19 \%$ ), $253.8 \mathrm{~Pa}$ (감 소율 $56 \%$ ) 및 $211.2 \mathrm{~Pa}$ (감소율 63\%)(Figure 4C), P/A값은 최 초 $4.6^{\circ}$ 에서 각각 $5.9^{\circ}, 6.9^{\circ}$ 및 $7.7^{\circ}$ 로 나타났다(Figure $4 \mathrm{D}$ ).

위의 결과로부터 알 수 있듯이 mannitol의 첨가농도에 따라 서 각각 유변학적인 항목인 $\mathrm{G}^{\prime}, \mathrm{G}^{\prime \prime}, \mathrm{G}^{*}$ 및 $\mathrm{P} / \mathrm{A}$ 농도 의존적인 효 과는 볼 수 없었으며, 첨가량 $1 \%$ 이상(가열시간 $45 \mathrm{~min}$ )에서 $\mathrm{G}^{*}$ 및 $\mathrm{P} / \mathrm{A}$ 값에서 mannitol을 첨가하지 않은 군 대비 유의한 효과 가 관찰되었다. 즉, mannitol은 가교 겔의 점탄성 성질을 균형 있게 유지하면서 열에 의한 점탄성 물성의 감소에 저항성을 주는 것으로 평가되었다.

\section{Mannitol의 이뇨 효과}

Table 2는 mannitol의 농도별에 따른 신장작용에 대하 결과 이다. Mannitol의 투여 농도에 따라서 투여 후 시간에 따른 뇨 량과 생화학적 관련 인자 들을 측정하였다. 그 결과 mannitol $1 \%$ 및 $5 \%$ 농도 투여군에서는 뇨량의 증가를 나타내었고, $5 \%$ 농 도 투여군에서는 유의적인 증가가 나타났다. 관련 생화학적인 지 표 들인 사구체여과율(glomerular filtration rate, GFR), 신 혈류량(renal plasma flow, RPF), 삼투질제거율(clearance of osmolar, Cosm), 평균혈압(mean arterial pressure, MAP) 및 뇨중의 $\mathrm{Na}^{+}$과 $\mathrm{K}^{+}$의 배설량 $\left(\mathrm{E}_{\mathrm{Na}}\right.$ 및 $\left.\mathrm{E}_{\mathrm{K}}\right)$ 이 증가하였으나 유의적 이지는 않았다. Mannitol 20\%의 경우는 뇨량과 동시에 사구체 여과율(GFR), 신혈류량( $\mathrm{RPF})$, 삼투질제거율(Cosm), 평균혈압 (MAP) 및 뇨중의 $\mathrm{Na}^{+}$과 $\mathrm{K}^{+}$의 배설량 $\left(\mathrm{E}_{\mathrm{Na}}\right.$ 및 $\left.\mathrm{E}_{\mathrm{K}}\right)$ 이 유의적으로 증가하였다. 이와 같이 mannitol의 경우는 혈류학적 개선에 의 해서 이뇨작용을 나타내는 것으로 평가되었다. 이러한 혈류학적 개선효과는 부종의 조절을 위하여 임상적으로 자주 사용되는 것 (Jeon, 2011)으로 가교 겔에 mannitol을 첨가하는 것은 이러한 생리활성을 충분히 기대할 수 있을 것으로 사료된다.

\section{Conclusion}

Mannitol은 항산화 효과가 우수한 polyol 계열의 ROS scavenger로 알려져 있다. 본 연구에서 이러한 mannitol의 항 산화 효과를 이용하여 가교 히알루론산 겔의 화학적 또는 가열에 의한 산화적 스트레스에 저항성이 있는 가교 겔을 구현하고자 하 였다.

그 결과 가교 겔에 mannitol의 첨가 유무에 따라서 가교 겔이 갖는 고유의 유변학적 물성인 탄성 $\left(\mathrm{G}^{\prime}\right)$, 점성 $\left(\mathrm{G}^{\prime \prime}\right)$, 복소점도 $\left(\mathrm{G}^{*}\right)$ 및 phase angle $(\mathrm{P} / \mathrm{A})$ 에 유의적인 영향을 미치는 것으로 나타 났다. Mannitol의 첨가는 가교 겔의 점탄성(viscoelasticity) 에 영향을 주는 탄성 $\left(\mathrm{G}^{\prime}\right)$ 및 점성 $\left(\mathrm{G}^{\prime \prime}\right)$ 에 있어서 frequency (변 형율)의 증가에 따라서 매우 안정적인 변화거동을 보였다. 따라 서 mannitol의 첨가로 인하여 frequency의 증가에 따른 스트레 스에 저항을 주어 frequency의 증가에 불구하고 가교 겔의 $\mathrm{G}^{\prime}$ 과 $\mathrm{G}^{\prime \prime}$ 급격한 증가나 감소에 영향을 미치지 않고 일정한 거동을 유 지해 주었다.

가교 겔의 화학적 산화에 대한 스트레스에 있어서도 mannitol 의 첨가에 따른 유변학적 물성을 보호해 주는 것으로 나타났다. 특히 $\mathrm{G}^{\prime}$ 과 $\mathrm{G}^{\prime \prime}$ 의 거동을 모두 종합하여 나타내는 복소점도 $\left(\mathrm{G}^{*}\right)$ 에 있어서 mannitol의 첨가가 과산화수소에 의한 산화적 스트레스 에 대한 저항성을 노출시간의 증가에 따라서 극명하게 관찰할 수 있었으며, 첨가량의 증가에 따라서 초기 $\mathrm{G}^{*}$ 값의 증가가 나타났 고 그 거동의 변화는 산화적 스트레스의 노출시간이 증가하여도 변화 없이 안정한 거동 양상을 나타내었다.

또한 가교 겔의 제조 후에 가열에 따른 안정성을 가열 시간의 증가에 따라서 관찰한 결과, mannitol의 첨가는 가열 시간이 증 가함에 따라서 열에 대한 산화적 스트레스에 대한 저항성을 나타 내었다. 농도에 따른 농도 의존적인 효과 보다는 열에 대한 노출 시간이 길어짐에 따라서 유변학적 물성 들의 감소에 대한 저항 효과가 더 잘 나타났다. 그 이유는 mannitol 자체가 열에 안정하 여 그 생리활성을 유지하기 때문으로 사료되었다.

의약품에서 mannitol의 약효로는 이뇨제로 수술 중 혹은 수술 후나 외상으로 인한 급성신부전의 예방 및 치료, 약물 중독 시의 배설 촉진, 뇌압 및 안압의 강하에 대한 적응증을 가지고 있다. 이로 인한 효과로 부종의 조절에 주로 사용되고 있다. 이러한 기 능은 가교 겔을 이용한 조직수복용 필러에서 발생할 수 있는 부 종의 감소에 영향을 줄 수 있다고 판단된다.

본 연구내용에서는 이러한 이뇨 효과를 측정함으로써 부종에 영향을 줄 수 있을 것으로 평가하였다. 본 연구에서는 mannitol 이 혼합된 가교 겔로 피하 투여로 인한 평가가 불가능하여 mannitol 용액으로 평가하였으나, 가교 겔을 이용하여 부종의 발생 유무를 직접 평가할 수 있는 동물 모델의 개발도 필요할 것 으로 사료된다. 
결론적으로 mannitol의 항산화 기능에 의하여 가교 히알루론 산 겔의 유변학적 성질을 개선시키는 것으로 평가되었다. 본 연 구의 결과로 기존의 의약품과는 다르게 성형 필러에서의 유발이 될 수 있는 부종을 예방할 수 있는 최소의 농도를 도출하였다는 데 의의가 있다고 판단된다.

\section{Acknowledgements}

본 연구는 중소벤처기업부의 2017년도 제4차 제품공정개선 기술개발사업에 의하여 이루진 것임(과제번호 S2561438).

\section{References}

Alijotas-Reig J, Garcia-Gimenez V. Delayed immune-mediated adverse effects related to hyaluronic acid and acrylic hydrogel dermal fillers: clinical findings, long-term followup and review of the literature. Journal of the European Academy of Dermatology and Venereology, 22: 150161, 2008.

Barnett HL, Hare K, McNamara H, Hare R. Measurement of glomerular filtration rate in premature infants. The Journal of Clinical Investigation, 27: 691-699, 1948.

Cameli N, Mariano M, Serio M, Berardesca E. Clinical and instrumental evaluation of a cross-linked hyaluronic acid filler dermal injection: effects on nasolabial folds skin biophysical parameters and augmentation from a single-dose, monocentric, open-label trial. Giornale Italiano Di Dermatologia E Venereologia, 151: 507-514, 2016.

Caspersen MB, Roubroeks JP, Qun L, Shan H, Fogh J, Ruidong Z, Tømmeraas K. Thermal degradation and stability of sodium hyaluronate in solid state. Carbohydrate Polymers, 107: 25-30, 2014.

Chien $\sqcup$, Lee CK. Enhanced hyaluronic acid production in Bacillus subtilis by coexpressing bacterial hemoglobin. Biotechnology Progress, 23: 1017-1022, 2007.

Chong BF, Blank LM, Mclaughlin R, Nielsen LK. Microbial hyaluronic acid production. Applied Microbiology and Biotechnology, 66: 341-351, 2005.

Chong BF, Nielsen LK. Amplifying the cellular reduction potential of Streptococcus zooepidemicus. Journal of Biotechnology, 100: 33-41, 2003.

Conrozier T, Mathieu P, Rinaudo M. Mannitol preserves the viscoelastic properties of hyaluronic acid in an in vitro model of oxidative stress. Rheumatology and Therapy, 1: 45-54, 2014.

da Costa A, Biccigo DGZ, de Souza Weimann ET, Mercadante LM, Oliveira PRG, Prebianchi SB, Abdalla BMZ. Durability of three different types of hyaluronic acid fillers in skin: are there differences among biphasic, monophasic monodensified, and monophasic polydensified products? Aesthetic Surgery Journal, 37: 573-581, 2017.

De Boulle K, Glogau R, Kono T, Nathan M, Tezel A, RocaMartinez JX, Paliwal S, Stroumpoulis D. A review of the metabolism of 1,4-butanediol diglycidyl ethercrosslinked hyaluronic acid dermal fillers. Dermatologic Surgery, 39: 1758-1766, 2013.

Fraser JR, Laurent TC, Pertoft H, Baxter E. Plasma clearance, tissue distribution and metabolism of hyaluronic acid injected intravenously in the rabbit. Biochemical Journal, 200: 415-424, 1981.

Funt D, Pavicic T. Dermal fillers in aesthetics: an overview of adverse events and treatment approaches. Clinical, Cosmetic and Investigational Dermatology, 6: 295-316, 2013.

Funt D, Pavicic T. Dermal fillers in aesthetics: an overview of adverse events and treatment approaches. Plastic Surgical Nursing, 35: 13-32, 2015.

Ha CW, Park YB, Choi CH, Kyung HS, Lee JH, Yoo JD, Yoo $\mathrm{JH}$, Choi CH, Kim CW, Kim HC, et al. Efficacy and safety of single injection of cross-linked sodium hyaluronate vs. three injections of high molecular weight sodium hyaluronate for osteoarthritis of the knee: a doubleblind, randomized, multi-center, non-inferiority study. BMC Musculoskeletal Disorders, 18: 223, 2017.

Heiene R, Moe L. Pharmacokinetic aspects of measurement of glomerular filtration rate in the dog: a review. Journal of Veterinary Internal Medicine, 12: 401-414, 1998.

Jeon US. Principles and practice of diuretic therapy. The Korean Journal of Medicine, 80: 8-14, 2011.

Jeong SH. Anti-oxidant activities of phytol on keratinocytes. Asian Journal of Beauty and Cosmetology, 15: 457-465, 2017.

Kogan G, Šoltés L, Stern R, Gemeiner P. Hyaluronic acid: a natural biopolymer with a broad range of biomedical and industrial applications. Biotechnology Letters, 29: 17-25, 2007. 
Kwon SB, Lee GT, Choi SJ, Lee NK, Park HW, Lee KS, Lee KK, Ahn KJ, An IS. The effect of glycerin, hyaluronic acid and silicone oil on the hydration, moisturization and transepidermal water loss in human skin. Asian Journal of Beauty and Cosmetology, 11: 761-768, 2013.

Laurent UB, Dahl LB, Reed RK. Catabolism of hyaluronan in rabbit skin takes place locally, in lymphnodes and liver. Experimental Physiology, 76: 695-703, 1991.

Lowe NJ, Maxwell CA, Patnaik R. Adverse reactions to dermal fillers: review. Dermatologic Surgery, 31: 1616-1625, 2005.

Makimoto G, Ichihara E, Hotta K, Ninomiya K, Oze I, Minami D, Ninomiya T, Kubo T, Ohashi K, Tabata M, et al. Randomized phase II study comparing mannitol with furosemide for the prevention of renal toxicity induced by cisplatin-based chemotherapy with short-term lowvolume hydration in advanced non-small cell lung cancer: the OLCSG1406 study protocol. Acta Medica Okayama, 72: 319-323, 2018.
Peters JP, Van Slyke DD. Quantitative clinical chemistry. The Williams \& Wilkins Company, Baltimore, pp596-606, 1944.

Reed RK, Laurent UB, Fraser JR, Laurent TC. Removal rate of $[3 \mathrm{H}]$ hyaluronan injected subcutaneously in rabbits. The American Journal of Physiology, 259: H532-H535, 1990.

Smith HW, Finkelstein N, Aliminosa L, Crawford B, Graber M. The renal clearances of substituted hippuric acid derivatives and other aromatic acids in dog and man. The Journal of Clinical Investigation, 24: 388-404, 1945.

Šoltés L, Kogan G, Stankovska M, Mendichi R, Rychlý J, Schiller J, Gemeiner P. Degradation of high-molarmass hyaluronan and characterization of fragments. Biomacromolecules, 8: 2697-2705, 2007. 


\section{국문초록}

\section{항산화제 만니톨의 히알루론산 가교체의 유변학적 성질 및 기능에 미치는 영향}

김이슬, 최복열, 강주희, 이경호*

아크로스, 강원도 춘천시, 한국

목적: 본 본 연구는 라디칼 소거제로인 만니톨 혼합에 의한 가교 히알루론산 겔의 유변학적 물성의 개선효과를 평가하기 위함이다. 방법: 가교겔의 제조공정에 따라서 만니톨을 혼합하여 가교겔을 제조하였으며, 그 유변학적 성질을 화학적 및 가열 산화적 스트레 스를 가하여 탄성 $\left(\mathrm{G}^{\prime}\right)$, 점성 $\left(\mathrm{G}^{\prime \prime}\right)$, 복소점도 $\left(\mathrm{G}^{*}\right)$ 및 위상각 $(\mathrm{P} / \mathrm{A})$ 을 측정하여 관찰하였다. 결과: 만니톨 혼합 가교겔은 주파수의 증가 및 화학적 또는 가열 산화적 스트레스에 대한 저항력을 나타내었다. 또한 동물실험에서 만니톨은 첨가농도에서 뇨 배출의 증진을 나타내었다. 이러한 결과는 삼투압에 의한 뇨 배출로 인한 부종의 감소를 기대할 수 있을 것으로 평가된다. 결론: 만니톨의 항산화 기능은 히알루론산 가교 겔의 유변학적 물성의 개선을 나타내었다.

핵심어: 히알루론산, 만니톨, 가교 겔, 유변학, 산화적 스트레스

본 연구는 중소벤처기업부의 2017년도 제4차 제품공정개선 기술개발사업에 의하여 이루진 것임(과제번호 S2561438).

\section{참고문헌}

권승빈, 이강태, 최성진, 이나경, 박현우, 이광식, 이건국, 안규중, 안인숙. 글리세린, 히알루론산, 실리콘 오일이 피부의 보습 및 경피수분손실량에 미치는 효과. 아시안뷰티화장품학술지, 11: 761-768, 2013. 전은실. 일차진료에서 흔히 접하는 수분 전해질 문제: 이뇨제 사용의 원칙과 실제. 대한내과학회지, 80: 8-14, 2011. 정선희. 인간각질형성세포에서 Phytol의 항산화 효능. 아시안뷰티화장품학술지, 15: 457-465, 2017. 


\section{中文摘要}

\section{甘露醇作为自由基清除剂混合改善交联透明质酸凝胶的流变性}

金瑟，崔福烈，姜周希，李庚鎬

(株)Across，江原道春川市，韩国

目的：评估将甘露醇混合到交联透明质酸凝胶中对其流变学特性的影响。方法：通过将甘露醇混合到我们自己的 制造过程中来制备交联的透明质酸凝胶, 然后研究由于化学和热氧化应力引起的其流变性质的变化。评价的流 变学因素是储能模量 $\left(G^{\prime}\right)$ ，损耗模量 $\left(G^{\prime}\right)$ ，复数粘度 $\left(G^{*}\right)$ 和相角 $(P / A)$ 。结果：将甘露醇混合到交联的 透明质酸凝胶中会使其弹性 $\left(G^{\prime}\right)$ 和粘度 $\left(G^{\prime \prime}\right)$ 抵抗由化学和热应力引起的频率增加和氧化应激。添加甘露醇 还可以改善动物模型中的尿液分泌。因此，我们希望它能减少因渗透压引起的水肿。结论: 甘露醇的抗氧化作用 有助于改善交联透明质酸凝胶的流变性质。

关键词: 透明质酸，甘露醇，交联凝胶，流变学，氧化应激 
